\title{
Study of Biochemical Parameters in Diabetic Patients with and without Diabetic Retinopathy - A Hospital based study
}

\author{
Joshi $\mathrm{I}^{1}$, Lavaju $\mathrm{P}^{2}$, Badhu $\mathrm{BP}^{3}$, Maskey $\mathrm{R}^{4}$, Lamsal $\mathrm{M}^{5}$ \\ ${ }^{1}$ Vitreo-Retina Consultant, Biratnagar Eye Hospital, Rani, Biratnagar, ${ }^{2} \mathrm{Head}$ of Department of \\ Ophthalmology, Professor, BPKIHS Dharan, ${ }^{3}$ Professor, Birat Medical College Teaching Hospital, \\ Tankisinwari, Biratnagar, ${ }^{4}$ Additional Professor, Department of Internal Medicine, BPKIHS, Dharan, \\ ${ }^{5}$ Professor, Department of Biochemistry, BPKIHS, Dharan.
}

\begin{abstract}
Background: Diabetic Retinopathy (DR) is a common, potentially blinding and visually disabling complication of diabetes. Early detection of retinopathy and its progression to severity with routine referral for screening by Ophthalmologist can save vision by timely management. Methods: This was a hospital based cross-sectional study done to study the association of glycated hemoglobin (HbA1c), fasting and postprandial blood sugar, serum lipid profile, serum creatinine and urine albumin in diabetic patient with and without DR. A total of 50 patients with Diabetic retinopathy and 50 patients without diabetic retinopathy were enrolled in this study. All patients included were Type 2 DM aged 35 years and above. Results: The mean HbA1c was $8.62 \pm 1.5$ and $5.54 \pm 1.2$, total cholesterol was $228.9 \pm 63$ and $184.9 \pm 39.8 \mathrm{mg} / \mathrm{dl}$, serum triglyceride was $226.6 \pm 80.7$ and $160.8 \pm 45.1 \mathrm{mg} / \mathrm{dl}$, LDL-C was $152.3 \pm 49$ and $127.2 \pm 37 \mathrm{mg} / \mathrm{dl}$ and serum creatinine was $1.15 \pm 0.45$ and $0.66 \pm 0.27 \mathrm{mg} / \mathrm{dl}$ in diabetic retinopathy group and no diabetic retinopathy group respectively. There was significant association of elevated $\mathrm{HbA} 1 \mathrm{c}$, serum triglyceride, LDL- C and total cholesterol with diabetic retinopathy in patients with type 2 DM. The mean values of serum lipoproteins were higher in the diabetic retinopathy group. Conclusion: Elevated fasting and postprandial blood sugar, glycated hemoglobin, total cholesterol, serum triglyceride, LDL-C, serum creatinine and urine albumin were significantly associated with DR in our study. So, all patients with diabetes mellitus should be screened routinely for serum lipoproteins along with blood sugar profile, as it would help in early detection of diabetic retinopathy.
\end{abstract}

Keywords: Type 2 Diabetes mellitus, Diabetic Retinopathy, Serum Lipoproteins

\section{Introduction:}

Diabetic Retinopathy (DR) is a common, potentially blinding and visually disabling complication of diabetes where the cause of vision loss can be due to diabetic maculopathy or complications of proliferative diabetic retinopathy (PDR). ${ }^{1}$ Diabetic patient are 25 times more likely than the general

Correspondence Author

Dr. Ichhya Joshi, Department of Vitreo Retina

Biratnagar Eye Hospital, Rani, Biratnagar 56613, Nepal

Tel +9779841420173

Emailichhyaj@gmail.com population to develop vision loss and blindness. ${ }^{2}$

Diabetes has emerged as a major global concern. In 2040, the global diabetes prevalence in adults is predicted to rise to $10.4 \% .^{3}$ In Nepal, the burden of diabetes is increasing rapidly due to increasing urbanization, aging population, rapid increase in obesity, and sedentary lifestyle. As per the recent meta-analysis, the prevalence of diabetes in Nepal was $8.5 \%{ }^{4}$

According to a hospital based study by Thapa et $\mathrm{al}^{5}$ and Shrestha et $\mathrm{al}^{6}$ in Nepal, the prevalence 
of diabetic retinopathy was $38 \%$ and $44.7 \%$ respectively. Long duration of diabetes, poor glycaemic control, high blood pressure, pregnancy and nephropathy are the known risk factors for diabetic DR. ${ }^{7}$ Biochemical parameters being the reflection of the state of control of diabetes are valuable resources in identifying the progression of retinopathy. However, there are little conclusive evidence regarding the association of biochemical parameters especially serum lipid profile with retinopathy in this region. So, the objective of this study was to study the association of glycated hemoglobin (HbAlc), fasting and postprandial blood sugar, serum lipid profile, serum creatinine and urine albumin in diabetic patient with and without DR.

\section{Methods:}

This was a hospital based cross-sectional study conducted at B.P. Koirala Institute of Health Science, Dharan, Nepal. Written Informed consent was obtained from all the patients enrolled in the study. The research was approved by the ethics committee and institutional board of BPKIHS, Dharan, Nepal on 22nd July 2014(Ref. No.ACd/10/071/072), and has adhered to the tenets of the Declaration of Helsinki.

A Total of 100 patients were enrolled in this study. Convenient sampling method was used. All patients with Type 2 DM with and without DR aged 35 years and above were included in the study. Patients were categorized as either presence or absence of DR. The patients with DR were classified as per ETDRS classification of Diabetic Retinopathy.8 Patients with Type 1 DM, Gestational diabetes mellitus, central corneal opacity, cataract obscuring detailed fundus evaluation, vitreous hemorrhage were excluded from the study. Detailed history was taken and all participants underwent a comprehensive ophthalmic examination. $\mathrm{HbA1c}$, fasting and postprandial blood sugar, lipid profile, and serum creatinine and urine albumin were evaluated. All the biochemical parameters except urinary albumin were measure by using the standard commercial assay kits in CobasC311 auto-analyzer, closed system in the biochemistry laboratory of BPKIHS, Dharan.

\section{Statistical analysis:}

All the data were entered in Microsoft Excel spreadsheet 2013 and converted into SPSS (Statistical Package for Social Science) version 17.0 program for statistical analysis. For inferential statistics, X2 test was used for categorical data, for comparison of mean $t$ test was used and for association between two continuous variable correlations was used.

\section{Results:}

A total of 50 patients with diabetic retinopathy and 50 patients without diabetic retinopathy were enrolled in the study. Out of 50 patients with DR, 28 had mild NPDR, 19 had moderate NPDR, 1 had severe NPDR with CSME and 1 had PDR with CSME.

The mean age was $59.56 \pm 10.9$ and $54.30 \pm 9.7$ years in patients with and without DR respectively. There was equal number of male and female in both groups. The mean duration of DM in DR group was $8.20 \pm 4.6$ years and in no DR group were $4.08 \pm 2.7$ years. Most of the patients in the DR group were housewives/retired and most of the patients in no DR group were businessmen. Forty two point nine percent of the patients on OHA $42.9 \%$ had DR whereas $57.1 \%$ had no DR. DR patients on insulin were $87.5 \%(\mathrm{P}=0.002)$. In those patients with $\mathrm{DR}$, only $22 \%$ had positive family history of diabetes while $78 \%$ had no family history of diabetes. In DR group, $74 \%$ were aware and $26 \%$ were not aware of DR as a complication of DM. The mean systolic blood pressure in DR group was $134.40 \pm 18.6 \mathrm{~mm}$ $\mathrm{Hg}$ and in no DR group was $126.60 \pm 15.8 \mathrm{mmHg}$. The mean diastolic blood pressure in DR group was $81.20 \pm 9.39 \mathrm{~mm} \mathrm{Hg}$ and in no DR group was $76.60 \pm 10 \mathrm{~mm} \mathrm{Hg}$. The mean BMI in the DR group was $25.91 \pm 2.8$ and in no DR group were 25.05 \pm 2.5 . Best corrected visual acuity of $\geq 6 / 18$ was present in $84 \%$ of the patients with DR and $16 \%$ had visual acuity of $<6 / 18$. In the patients without DR, right eye was considered for evaluation and $100 \%$ had visual acuity of $\geq 6 / 18$. The mean CCT in the patients with DR was $533.7 \pm 17.9$ and in those without DR was $513.9 \pm 29$. 
The mean fasting blood sugar was $120 \pm 1 \mathrm{mg} / \mathrm{dl}$ and $119.86 \pm 63.6 \mathrm{mg} / \mathrm{dl}$ in DR group and no DR group respectively $(\mathrm{P}<0.001)$. The mean postprandial blood sugar in the patients was $272.5 \pm 91.8 \mathrm{mg} / \mathrm{dl}$ and $192.6 \pm 63.6 \mathrm{mg} / \mathrm{dl}$ in DR group and no DR group respectively $(\mathrm{P}<0.001)$. The mean glycated hemoglobin in the patients with DR was $8.62 \pm 1.5 \%$ and in those without DR was $5.54 \pm 1.2 \%(\mathrm{P}<0.001)$. (Table 1$)$

Table 1: Blood sugar

\begin{tabular}{|c|c|c|c|c|c|c|c|}
\hline \multirow{2}{*}{$\begin{array}{l}\text { Fasting Blood } \\
\text { sugar (mg/dl) }\end{array}$} & \multicolumn{3}{|c|}{ Diabetic retinopathy $(\mathrm{N})$} & \multirow{2}{*}{$\begin{array}{l}\text { Odds } \\
\text { ratio }\end{array}$} & \multicolumn{2}{|c|}{$\begin{array}{l}\text { 95\% Confidence } \\
\text { Interval }\end{array}$} & \multirow[t]{2}{*}{ P-value } \\
\hline & Yes & No & Total & & Lower & Upper & \\
\hline$\leq 126$ & $7(18.9 \%)$ & $30(81.1 \%)$ & $37(100 \%)$ & \multirow{2}{*}{0.109} & \multirow{2}{*}{0.041} & \multirow{2}{*}{0.289} & \multirow{2}{*}{$<0.001$} \\
\hline$>126$ & $43(68.3 \%)$ & $20(31.7 \%)$ & $63(100 \%)$ & & & & \\
\hline \multicolumn{8}{|c|}{ Postprandial blood sugar $(\mathrm{mg} / \mathrm{dl})$} \\
\hline$\leq 200$ & $8(19.5 \%)$ & $33(80.5 \%)$ & $41(100 \%)$ & \multirow{2}{*}{0.098} & \multirow{2}{*}{0.038} & \multirow{2}{*}{0.255} & \multirow{2}{*}{$<0.001$} \\
\hline$>200$ & $42(71.2 \%)$ & $17(28.8 \%)$ & $59(100 \%)$ & & & & \\
\hline \multicolumn{8}{|l|}{ HbA1c (\%) } \\
\hline$<7$ & $5(10.6)$ & $42(89.4 \%)$ & $47(100 \%)$ & \multirow{2}{*}{0.021} & \multirow{2}{*}{0.006} & \multirow{2}{*}{0.070} & \multirow{2}{*}{$<0.001$} \\
\hline$\geq 7$ & $45(84.9)$ & $8(15.1 \%)$ & $53(100 \%)$ & & & & \\
\hline
\end{tabular}

The mean level of total cholesterol in the patients with DR was $228.9 \pm 63 \mathrm{mg} / \mathrm{dl}$ and in those without DR was $184.9 \pm 39.8 \mathrm{mg} / \mathrm{dl}$. The mean HDL-C in the patients with DR was $40.6 \pm 8.0 \mathrm{mg} / \mathrm{dl}$ and in those without DR was $40.12 \pm 9.5 \mathrm{mg} / \mathrm{dl}$. The mean serum triglyceride in the patients with DR was $226.6 \pm 80.7 \mathrm{mg} / \mathrm{dl}$ and in those without DR was $160.8 \pm 45.1 \mathrm{mg} / \mathrm{dl}$. The mean LDL-C in the patients with DR was $152.3 \pm 49.1 \mathrm{mg} /$ $\mathrm{dl}$ and in those without DR was $127.2 \pm 37.3 \mathrm{mg} / \mathrm{dl}$.

The mean serum creatinine in the patients with DR was $1.56 \pm 0.43 \mathrm{mg} / \mathrm{dl}$ and in those without DR was $0.78 \pm 0.22$ $\mathrm{mg} / \mathrm{dl}$. In the patients with serum creatinine level $>1.2 \mathrm{mg} / \mathrm{dl}$ (male) and $>1 \mathrm{md} / \mathrm{dl}$ (female), DR was seen in $91.8 \%$ of the patients $(\mathrm{P}<0.001)$. In the patients with albuminuria, 78.2\% (43) had DR $(\mathrm{P}<0.001)$. (Table 2$)$

Table 2: Lipid profile, serum creatinine and urine albumin

\begin{tabular}{|c|c|c|c|c|c|c|c|}
\hline \multirow{2}{*}{$\begin{array}{c}\text { Total Cholesterol } \\
(\mathrm{mg} / \mathrm{dl})\end{array}$} & \multicolumn{3}{|c|}{ Diabetic retinopathy $(\mathrm{N})$} & \multirow{2}{*}{$\begin{array}{l}\text { Odds } \\
\text { ratio }\end{array}$} & \multicolumn{2}{|c|}{$\begin{array}{l}\text { 95\% Confidence } \\
\text { Interval }\end{array}$} & \multirow[t]{2}{*}{ P-value } \\
\hline & Yes & No & Total & & Lower & Upper & \\
\hline$\leq 200$ & $13(24.1 \%)$ & $41(75.9 \%)$ & $54(100 \%)$ & \multirow{2}{*}{0.077} & \multirow{2}{*}{0.030} & \multirow{2}{*}{0.201} & \multirow{2}{*}{$<0.001$} \\
\hline$>200$ & $37(80.4 \%)$ & $9(19.6 \%)$ & $46(100 \%)$ & & & & \\
\hline \multicolumn{8}{|l|}{ HDL-C (mg/dl) } \\
\hline$<40$ & $27(48.2 \%)$ & $29(51.8 \%)$ & $56(100 \%)$ & \multirow{2}{*}{0.850} & \multirow{2}{*}{0.386} & \multirow{2}{*}{1.874} & \multirow{2}{*}{0.687} \\
\hline$>40$ & $23(52.3 \%)$ & $21(47.7 \%)$ & $44(100 \%)$ & & & & \\
\hline \multicolumn{8}{|c|}{ Serum Triglyceride (mg/dl) } \\
\hline$\leq 150$ & $7(25.9 \%)$ & $20(74.1 \%)$ & $27(100 \%)$ & \multirow{2}{*}{0.244} & \multirow{2}{*}{0.092} & \multirow{2}{*}{0.650} & \multirow{2}{*}{0.003} \\
\hline$>150$ & $43(58.9 \%)$ & $30(41.1 \%)$ & $73(100 \%)$ & & & & \\
\hline \multicolumn{8}{|l|}{ LDL-C (mg/dl) } \\
\hline$<160$ & $24(38.1 \%)$ & $39(61.9 \%)$ & $63(100 \%)$ & \multirow{2}{*}{0.260} & \multirow{2}{*}{0.109} & \multirow{2}{*}{0.621} & \multirow{2}{*}{0.002} \\
\hline$\geq 160$ & $26(70.3 \%)$ & $11(29.7 \%)$ & $37(100 \%)$ & & & & \\
\hline
\end{tabular}




\begin{tabular}{|c|c|c|c|c|c|c|c|}
\hline \multirow{2}{*}{$\begin{array}{l}\text { Serum creatinine } \\
(\mathrm{mg} / \mathrm{dl})\end{array}$} & \multicolumn{3}{|c|}{ Diabetic retinopathy $(\mathrm{N})$} & \multirow{2}{*}{$\begin{array}{l}\text { Odds } \\
\text { ratio }\end{array}$} & \multicolumn{2}{|c|}{$\begin{array}{l}\text { 95\% Confidence } \\
\text { Interval }\end{array}$} & \multirow[t]{2}{*}{ P-value } \\
\hline & Yes & No & Total & & Lower & Upper & \\
\hline $\begin{array}{l}\leq 1.2(\text { male }) ; \leq 1 \\
\text { (Female) }\end{array}$ & $5(9.8 \%)$ & $46(90.2 \%)$ & $51(100 \%)$ & \multirow{2}{*}{0.010} & \multirow{2}{*}{0.002} & \multirow{2}{*}{0.038} & \multirow{2}{*}{$<0.001$} \\
\hline $\begin{array}{l}>1.2 \text { (male); }>1 \\
\text { (Female) }\end{array}$ & $45(91.8 \%)$ & $4(8.2 \%)$ & $49(100 \%)$ & & & & \\
\hline \multicolumn{8}{|l|}{ Urine Albumin } \\
\hline No albuminuria & $7(15.6 \%)$ & $38(84.4 \%)$ & $45(100 \%)$ & \multirow{2}{*}{0.051} & \multirow{2}{*}{0.018} & \multirow{2}{*}{0.144} & \multirow{2}{*}{$<0.001$} \\
\hline Albuminuria & $43(78.2 \%)$ & $12(21.8 \%)$ & $55(100 \%)$ & & & & \\
\hline
\end{tabular}

\section{Correlation:}

In this study, $51.1 \%$ with poor HbA1c control had mild NPDR. (Table 3)

Table 3: Relation of Glycated Hemoglobin with Stages of Diabetic retinopathy

\begin{tabular}{|l|l|l|}
\hline \multirow{2}{*}{$\begin{array}{c}\text { Stage of diabetic } \\
\text { retinopathy }\end{array}$} & \multicolumn{2}{|c|}{$\begin{array}{c}\text { Glycated hemoglobin } \% \\
\text { control }<7 \%\end{array}$} \\
\cline { 2 - 3 } $\begin{array}{c}\text { Poor control } \\
\geq 7 \%\end{array}$ \\
\hline Mild NPDR & $5(100 \%)$ & $23(51.1 \%)$ \\
\hline Moderate NPDR & 0 & $19(42.2 \%)$ \\
\hline $\begin{array}{l}\text { Severe NPDR with } \\
\text { CSME }\end{array}$ & 0 & $1(4.4 \%)$ \\
\hline PDR with CSME & 0 & $2(2.2 \%)$ \\
\hline Total & $5(100 \%)$ & $45(100 \%)$ \\
\hline
\end{tabular}

Serum triglyceride and serum creatinine showed low degree of positive correlations with abnormal $\mathrm{HbA} 1 \mathrm{c} \geq 7 \%$. (Table 4 )

Table 4: Correlation between abnormal HbA1C and serum lipoproteins in patients with Diabetic Retinopathy

\begin{tabular}{|l|l|l|}
\hline Blood Parameters & \multicolumn{1}{|c|}{$\begin{array}{c}\text { karl-Pearson } \\
\text { correlation } \\
\text { coefficient } r\end{array}$} & P-value \\
\hline S. Triglyceride & 0.055 & 0.707 \\
\hline T.Cholesterol & -0.041 & 0.779 \\
\hline HDL-C & -0.132 & 0.361 \\
\hline LDL-C & -0.163 & 0.259 \\
\hline S. creatinine & 0.166 & 0.25 \\
\hline
\end{tabular}

\section{Discussion:}

In our study, there was significant association of fasting blood sugar with DR $(\mathrm{P}<0.001)$. Among the patients with DR, $68.3 \%$ had fasting blood sugar of $>126 \mathrm{mg} /$ dl. El Hadd et.al ${ }^{9}$ showed that a high fasting capillary glucose level was significantly related to occurrence of retinopathy $(\mathrm{P}=0.002)$. The fasting capillary glucose level in patients with DR was $9.8 \mathrm{mmol} / 1$ and with no DR was $8.5 \mathrm{mmol} / 1$. Samatha et $\mathrm{a}^{10}$ found that there was significant increase in fasting blood sugar in patients with $\mathrm{DR}(\mathrm{P}<0.001)$.

There was significant association of postprandial blood sugar with DR in our study $(\mathrm{P}<0.001)$. Among the patients with $\mathrm{DR}, 71.2 \%$ had postprandial blood sugar of $>200 \mathrm{mg} / \mathrm{dl}$. El Bab et $\mathrm{al}^{11}$ showed that the patients with DR had significantly higher postprandial glucose.

Significant association of glycated hemoglobin with DR was shown in our study $(\mathrm{P}<0.001)$. Among the patients with DR, $84.9 \%$ had poor control $(\geq 7 \%)$ of HbAlc. In a study by Shakya et al ${ }^{12}$ the mean glycated hemoglobin was significantly higher in the DR group $(7.7 \pm 1.5 \%)$ compared to no diabetic retinopathy group $(6.9 \pm 1.1 \%)(\mathrm{P}=0.004)$. Various other studies also showed significant association of poor glycemic control with DR..$^{13,14,15,16}$

In our study, there was significant association of elevated total cholesterol with DR $(\mathrm{P}<0.001)$. Among the patients with DR, $80.4 \%$ had total cholesterol $>200 \mathrm{mg} / \mathrm{dl}$. Samatha et $\mathrm{al}^{10}$ showed 
significance association of elevated total cholesterol with DR. The mean total cholesterol in patients with DR was $187.53 \pm 57 \mathrm{mg} / \mathrm{dl}$ and in those without DR was $167.79 \pm 29 \mathrm{mg} / \mathrm{dl}$.

However, there was no significant association of HDL-C with DR in our study $(\mathrm{P}=0.687)$. However, $\mathrm{El} \mathrm{Bab}$ et all1 found that there was significant change of HDL-C from $2.66 \pm 0.3 \mathrm{mmol} / \mathrm{L}$ and $2.55 \pm 0.21 \mathrm{mmol} / \mathrm{L}$ for no $\mathrm{DR}$ and $\mathrm{DR}$ patients, respectively $(\mathrm{P}<0.05)$.

Our study showed significant association of serum triglyceride with DR $(\mathrm{P}=0.003)$. Among the patients with DR, $58.9 \%$ had serum triglyceride $>$ $150 \mathrm{mg} / \mathrm{dl}$. Shakya et $\mathrm{l}^{12}$ showed that the serum triglyceride value was higher in the group with DR but was statistically not significant $(\mathrm{P}=0.56)$. Serum triglyceride had low degree of positive correlation with $\mathrm{HbA1c}$ value. Similarly, Dayanand et a $1^{17}$ and Mohan $\mathrm{R}$ et $\mathrm{al}^{18}$ showed that hypertriglyceridemia was significantly associated with $\mathrm{DR}(\mathrm{P}<0.05)$.

Our study also showed significant association of LDL-C with DR ( $\mathrm{p}=0.002)$. Among the patients with DR, $70.3 \%$ had LDL-C $\geq 160 \mathrm{mg} / \mathrm{dl}$. Samatha et a ${ }^{10}$ however did not showed significant association of LDL-C with DR.

In our study, there was significant association of elevated serum creatinine with DR $(\mathrm{P}<0.001)$. Studies done by Cai et $\mathrm{al}^{15}$ and EL Haddad et $\mathrm{al}^{9}$ also showed significant association of elevated serum creatinine with DR.

There was significant association of urine albumin with DR in our study $(\mathrm{P}<0.001)$. Among the patients with DR, 78.2\% had albuminuria. Cai et al ${ }^{15}$ showed significant difference in urine albumin in patients with and without DR $(\mathrm{P}<0.001)$. Raman et al19, Klein et $\mathrm{al}^{20}$ and Shammari et $\mathrm{a}^{21}$ showed that microalbuminuria was significantly associated with DR.

In our study, serum triglyceride level and total cholesterol had a low degree of positive correlation with HbA1c level. Similar to our study, Shakya et $\mathrm{al}^{12}$ showed a low degree of positive correlation of serum triglyceride with $\mathrm{HbA} 1 \mathrm{c}$.

\section{Limitation and Recommendation:}

The limitations of our study were convenient sampling method and small sample size. A study with large sample size would be more conclusive.

As our study showed positive association of higher serum lipoprotein with diabetic retinopathy, it is recommended that all patients with diabetes mellitus should be screened routinely for serum lipoproteins along with blood sugar profile, as it would help in early detection of diabetic retinopathy and thereby help in prevention of ocular complications.

\section{Conclusion:}

In our study, elevated fasting and postprandial blood sugar, glycated hemoglobin, total cholesterol, serum triglyceride, LDL-C, serum creatinine and urine albumin were significantly associated with DR.

\section{List of abbreviations:}

DM Diabetes Mellitus, DR Diabetic Retinopathy, LDL-C Low density lipoprotein cholesterol, HDL-C High density lipoprotein cholesterol, HbA1c Glycated hemoglobin

ETDRS Early Treatment Diabetic Retinopathy Study, PDR Proliferative diabetic retinopathy, NPDR Non-proliferative diabetic retinopathy, CSME Clinically significant macular edema, CCT Central corneal thickness.

\section{Disclosure:}

The authors declare no conflict of interest.

\section{Authors' contributions:}

IJ conceptualized, collected data, analyzed and wrote the manuscript. PL, BPB, RM, ML supervised and guided throughout from the beginning of the study and critically reviewed the manuscript. All authors read and approved the final manuscript.

\section{References:}

1. Nentwich MM, Ulbig MW. Diabetic retinopathy - ocular complications of diabetes mellitus. World J Diabetes. 2015;6(3):489-499.

2. Orenstein B.W. Diabetes and your risk for vision loss [Internet]. [Last updated: April 21, 2015]. Available from: https://www. everydayhealth.com 
3. Ogurtsova K, Fernandes J.D. da Rocha, Huang Y, Linnenkamp U, Guariguata L, Cho N.H, et al. IDF Diabetes Atlas: Global estimates for the prevalence of diabetes for 2015 and 2040. Diabetes Research and Clinical Practice. June 2017;128;40-50.

4. Shrestha, N., Mishra, S.R., Ghimire, S. et al. Burden of Diabetes and Prediabetes in Nepal: A Systematic Review and Meta-Analysis. Diabetes Ther 11, 1935-1946 (2020).

5. Thapa R, Joshi DM, Rizyal A, Maharjan N, Joshi RD. Prevalence, risk factors and awareness of diabetic retinopathy among admitted diabetic patients at a tertiary level hospital in Kathmandu. Nepal J Ophthalmol 2014; 6 (2): 24-30.

6. Shrestha MK, Paudyal G, Wagle RR, Gurung $\mathrm{R}$, Ruit S and Onta SR. Prevalence of and factors associated with diabetic retinopathy among diabetics in Nepal: a hospital based study. Nepal Med Coll J. 2007; 9(4):225-229.

7. Unger RH, Foster DW. Diabetes Mellitus. William's text book of Endocrinology. Eighth edition. Philadelphia; 1992; page 1011-1025.

8. Early Treatment Diabetic Retinopathy Study Research Group. Early Treatment Diabetic Retinopathy Study design and baseline patient characteristics. ETDRS Report number 7. Ophthalmology 1991; 98:742.

9. El Haddad OAW, Saad MK. Prevalence and risk factors for diabetic retinopathy among Omani diabetics. Br J Ophthalmol 1998; 82:901-906.

10. Samatha P, Venkateswarlu M, Prabodh V.S. The role of biochemical markers in the prediction of microvascular complications in type $2 \mathrm{DM}$. Journal of Clinical and Diagnostic Research. 2011 November (Suppl-1); 5(6):1154- 1157.

11. El-Bab MF, Zaki NS, Mojaddidi MA, Al-Barry M, El-Beshbishy HA. Diabetic retinopathy is associated with oxidative stress and mitigation of gene expression of antioxidant enzymes. International Journal of General Medicine 2013; 6:799-806.

12. Shakya K, Shrestha JK, Joshi SN. Association between diabetic retinopathy and serum lipoproteins level. Nep J Oph 2009; 1(2):107-113.
13. Mohan R, Sundaram PK, Balaji A, Raj D, Rajendra P, Viswanathan M. Prevalence of diabetic retinopathy in urban India: The Chennai Urban Rural Epidemiology Study (CURES) Eye Study I. Investigative Ophthalmology and Visual Science, July 2005;46(7):2328-2333.

14. Janghorbani M, Amini M, Ghanbari H, Safaiee $\mathrm{H}$. Incidence of and risk factors for diabetic retinopathy in Isfahan, Iran. Ophthalmic Epidemiol. April 2003; 10(2):81-95.

15. Cai Xl, Wand F, JI L. Risk factors of diabetic retinopathy in type 2 DM. Chin Med J 2006; 119(10):822-826.

16. Klein R, Klein BEK, Moss SE, Davis MD, Demets DL. The Wisconsin epidemiologic study of diabetic retinopathy III. Prevalence and risk of DR when age at diagnosis is 30years or more. Arch Ophthalmol 1984; 102(4):527-532.

17. Dayanand CD, KrishnaMurthy N, Asha Kiran S, Naveen. Evaluation of Biochemical parameters evincing atherogenic potency in type 2 Diabetic Retinopathy. Int J Biol Med Res. 2011; 2(2):539-542.

18. Mohan R, Srivastava BK, Balaji A, Raj D, Viswanathan M. Association of serum lipids with diabetic retinopathy in urban South Indians-The Chennai Urban Rural Epidemiology Study (CURES) Eye Study-2. Diabetic Medicine 2006; 23:1029-1036.

19. Raman R, Gupta A, Kulothunga V, Sharma T. Prevelance and Risk factors for diabetic retinopathy in subjects with suboptimal glycemic, blood pressure and lipid control.Sankara Nethralaya Diabetic Retinopathy Epidemiology and Molecular Genetic Study (SN-DREAMS, Report 33) June 2012, 37( 6): 513-523.

20. Klein R, Klein BEK, Moss SE, Davis MD, Demets DL. The Wisconsin epidemiologic study of diabetic retinopathy II. Prevalence and risk of DR when age at diagnosis is less than 30years. Arch Ophthalmol 1984; 102:520-6.

21. Al-Shammari F, Al-Meraghi O, Nasif A, AlOtaibi S. The prevalence of diabetic retinopathy and associated risk factors in Type II diabetes mellitus in Al-Naeem area (Kuwait). Middle East Journal of Family Medicine, 2005; Vol. 3(2). 